\title{
In vitro and In vivo Antioxidant, Anti-hyperlipidemic Properties and Chemical Characterization of Centella asiatica (L.) Extract
}

\author{
Sima Kumari', Meetali Deori', R. Elancheran², Jibon Kotoky² and Rajlakshmi Devi' * \\ ' Biochemistry Laboratory, Life Sciences Division, Institute of Advanced Study in Science and Technology, Guwahati, India, \\ 2 Drug Discovery Laboratory, Life Sciences Division, Institute of Advanced Study in Science and Technology, Guwahati, India
}

OPEN ACCESS

Edited by:

Aiping Lu,

Hong Kong Baptist University, China

Reviewed by:

Subhalakshmi Ghosh,

Jadavpur University, India

Adeyemi Oladapo Aremu,

University of KwaZulu-Natal,

South Africa

${ }^{*}$ Correspondence:

Rajlakshmi Devi

rajiasst@gmail.com

Specialty section:

This article was submitted to

Ethnopharmacology,

a section of the journal

Frontiers in Pharmacology

Received: 05 July 2016 Accepted: 11 October 2016

Published: 28 October 2016

Citation:

Kumari S, Deori M, Elancheran R, Kotoky J and Devi $R$ (2016) In vitro

and In vivo Antioxidant,

Anti-hyperlipidemic Properties and Chemical Characterization of Centella asiatica (L.) Extract.

Front. Pharmacol. 7:400

doi: 10.3389/fphar.2016.00400
The study aimed to identify the phenolic compounds present in Centella asiatica (L.) (C. asiatica) extract and evaluate the respective antioxidant potential as well as its cholesterol-lowering effects in the experimental animal model. Herein, the antioxidant potential of extracts was assessed by its free radical scavenging activity such as 2 , 2-diphenyl -1- picrylhydrazyl as well as reducing capability. The anti-hyperlipidemic effects of $C$. asiatica extract (CAE) were evaluated in high cholesterol-fed (HCF) rats for 4 weeks, where different concentrations of extracts $(0.25,0.5$, and $1 \mathrm{~g} / \mathrm{kg} /$ day) were orally administrated daily. Lipid and antioxidant profiles, including total cholesterol (TC), triglyceride (TG), low density lipoprotein cholesterol (LDL-C), high density lipoprotein cholesterol (HDL-C) and superoxide dismutase (SOD), together with the indices of hepatic functions were also examined. C. asiatica revealed excellent free radical scavenging activity as revealed by 2-2- diphenyl-1-picryl-hydrazyl (DPPH) assay, with the $\mathrm{IC}_{50}$ values $(9.62 \pm 0.88 \mu \mathrm{g} / \mathrm{mL})$. Furthermore, $C$. asiatica extracts and fenofibrate remarkably lowered the level of TC, TG, LDL-C, and showed elevated levels of HDLC, SOD. The histopathological observations further demonstrated clear differentiation and structural changes in liver of HCF and CAE treated group. Furthermore, gulonic acid, ferulic acid, kaempferol, chlorogenic acid, and asiatic acid were identified to be the major components which might be responsible for the antioxidant activity of the C. asiatica extract as evidenced from an ultra-high performance liquid chromatographymass spectrometer. Taken together, these results signifies the excellent antioxidant and anti-hyperlipidemic properties of $C$. asiatica leaf extracts, which might be useful for the treatment of oxidative-stress related diseases such as hyperlipidemia.

Keywords: Centella asiatica, antioxidant, anti-hyperlipidemic, medicinal plants, UHPLC-MS/MS

\section{INTRODUCTION}

Oxidative stress (OS) is essentially an imbalance between the production of free radicals, such as superoxide $\left(\mathrm{O}_{2}^{-}\right)$, hydroxyl $(\mathrm{OH})$, and peroxyl $(\mathrm{ROO})$ radicals and the ability of the body to counteract or detoxify their harmful effects through neutralization by antioxidants. OS leads to many chronic and degenerative diseases such as cancer, atherosclerosis, Parkinson's, Alzheimer's, diabetes, neurodegenerative disorders, and aging ( $\mathrm{Yu}, 1994$; Raghuveer and Tandon, 2009). 
Overproduction of these radicals can lead to the above mentioned disorders with as a consequence of "OS/oxidative damage." In earlier reports, various synthetic antioxidant compounds such as butylated hydroxyanisole (BHA), butylated hydroxytoluene (BHT), tertiary butylhydroquinone (TBHQ), and propyl gallate (PG) have shown effectiveness in the human body against oxidative damage caused by free radicals (Issa et al., 2006; Kaliora et al., 2006). However, the utilization of synthetic antioxidants is restricted now a day due to their toxicity and undesirable effects on human health (Sasaki et al., 2002; Bajpai et al., 2014).

Hyperlipidemia is represented by elevated levels of plasma lipid, serum cholesterol, and triglyceride (TG) and remains one of the major risk factors for coronary heart diseases (CHD), especially, the increased plasma low-density lipoprotein level can accelerate atherosclerosis (Arsenault et al., 2009; Harchaoui et al., 2009; de Lemos et al., 2010; Berry et al., 2012; Ma et al., 2012). The excessive intake of exogenous TG and cholesterol is associated with an elevated risk of atherosclerotic disease, which is regarded as a lipid storage disease with arterial deposition of cholesterol, endothelial injury and platelet aggregation (Liao et al., 2000). Several research groups have demonstrated that with the improvement of serum lipid profile, such as total cholesterol (TC), TG, and (TC-HDL-C)/HDL-c decreases liver lipid accumulation and lipid absorption. Therefore, the increasing serum/liver antioxidant capacity represents the most effective way for combating the occurrence of cardiovascular or liver disorders (Yang D.J. et al., 2010; Yang S.F. et al., 2010; Chang et al., 2011; Hsu et al., 2011; Liu et al., 2012; Lin et al., 2013).

Medicinal plants are rich sources of important metabolites, which are potential sources of antioxidant, antimicrobial, antiinflammatory, and anticancer activities (Hernandez et al., 2000; Polya, 2003; Maruthanila et al., 2014). The utilization of herbal medicine in treating infectious diseases have been practiced for 1000s of years and will continue to provide mankind with new remedies (Cragg and Newman, 2007). Earlier reports have demonstrated a distinct correlation between the higher intake of plant foods and lower risk of mortality from diseases (Chidambaram et al., 2013). Recent interest has escalated in the finding antioxidant properties of natural origin plants due to their superior safety and consumer acceptability (Gorinstein et al., 2003). Additionally, approximately $60 \%$ of the commercially available anti-tumor and anti-infective agents are natural in origin (Shridhar et al., 2009). North Eastern (NE) region of India represents one of the mega biodiversity hotspots of the world and harbors a large number of medicinal plants. Around $80 \%$ of the population relies mainly on traditional medicine for their primary healthcare needs due to the high cost of western medicine (Rai and Lalramnghinglova, 2010; Lokho, 2012).

Centella asiatica (Family, Apiaceae) is commonly known as Centella and Gotu kola. It is native to India and other parts of Asia such as China, Sri Lanka, Nepal and Madagascar and has been utilized in folk medicine in different countries (Gohil et al., 2010). C. asiatica has been reported for the treatment of varicose veins, chronic venous insufficiency, psoriasis, minor wounds, analgesic, and anti-inflammatory effects (Pronprapa et al., 2010; Somboonwong et al., 2012). The primary constituents of $C$. asiatica are saponins (also called triterpenoids), which include asiaticosides, brahmoside, asiatic acid, and brahmic acid (madecassic acid) (Joshi and Chaturvedi, 2013). These triterpene saponins and their sapogenins are mainly responsible for the wound healing and vascular effects, which acts by inhibiting the production of collagen at the wound site (Seevaratna et al., 2012; Joshi and Chaturvedi, 2013). Other components isolated from C. asiatica, such as brahmoside and brahminoside, may be responsible for central nervous system (CNS) and uterorelaxant actions, but are yet to be confirmed by clinical studies (Orhan, 2012; Seevaratna et al., 2012; Joshi and Chaturvedi, 2013). In a recent study, researchers have utilized $C$. asiatica for wound healing activities of different extracts in partial-thickness burn wound models in rats (Somboonwong et al., 2012). In our previous report, we have identified and characterized phenolic compounds in C. asiatica by using UHPLC-MS/MS (Kumari et al., 2016). However, its anti-hyperlipidemic activities in rat fed with high-fat diet have not been documented yet from NE region. Therefore, we have designed this study in order to demonstrate the anti-hyperlipidemic activity of $C$. asiatica extracts in normal and high cholesterol-fed (HCF)-induced hyperlipidemic rat, which is the crucial factor in the treatment of oxidative-stress related diseases.

\section{MATERIALS AND METHODS}

\section{Sample Collection}

Centella asiatica plant was collected from the Sixmile, Guwahati, and Kamrup district of Assam (situated in between $25^{\circ} 43^{\prime}-$ $26^{\circ} 53^{\prime}$ North latitude and $90^{\circ} 39^{\prime}-92^{\circ} 11^{\prime}$ East latitude in the month of June to August 2015). The plant was authenticated and reconfirmed in the Department of Botany, Gauhati University, Assam. Herbarium C. asiatica (voucher specimens number: IASST/BCCS/HNO21/2013), was deposited in the Life Science Division (LSD) of the Institute of Advanced Study in Science and Technology (IASST), Guwahati, India for future references.

\section{Sample Preparation}

Freshly collected plant (C. asiatica) was washed twice with distilled water, dried at room temperature, powdered and used for extraction. The dried plant powder (100 g) was dissolved in $1000 \mathrm{~mL}$ of distilled water for $72 \mathrm{~h}$ with occasional shaking. The extract was further filtered through Whatman No. 1 filter paper and the filtrate was concentrated using a bench top lyophilizer under reduced pressure. The extract was stored at $4^{\circ} \mathrm{C}$ until further use in the designated experiment.

\section{Chemicals and Reagents}

Standards, such as DPPH, 2,2'-azinobis-3-ethyl benzothiazole6-sulfonic acid (ABTS), trolox, ascorbic acid and standard hyperlipidemic drug, i.e., Fenofibrate and standard enzyme used for catalase, SOD and diagnostic kits for measuring TC, TG, high density lipoprotein- cholesterol (HDL-C), were purchased from Sigma-Aldrich. Methanol (Fischer Scientific) and ethyl acetate (Merck) were procured. Potassium ferricyanide, 
trichloroacetic acid (TCA), ferric chloride, sodium nitroprusside, naphthyl ethylenediamine dichloride, sulfanilamide, phosphoric acid, sodium hydroxide, sodium chloride, hydrochloric acid, ferrozine, and ferrous chloride were obtained from HiMedia laboratory, India.

\section{UHPLC-ESI Orbitrap MS/MS Analysis}

The chromatographic separation was carried out using an ultra-high performance liquid chromatography (UHPLC) system coupled with an electron spray ionization (ESI) Orbitrap mass spectrometer. A series of 3100 UHPLC system (Dionex, Inc., Sunnyvale, CA, USA) is equipped with a binary pump, a degasser, an autosampler, a thermostated column compartment, and control module. The chromatographic separation was on a Hypersil Gold C18 column (1.9) operated at $25^{\circ} \mathrm{C}$. Gradient chromatographic separation was performed for each extract of the samples by using the previous method (Kumari et al., 2016). The screening and identification of the phenolic compounds in the $C$. asiatica extract were determined by using mass spectrum and its unique fragmentation spectrum. The comparison of the observed MS/MS spectra with those found in the literature and mass bank database was the main tool for putative identification of the phenolic compounds.

\section{In vitro Measurement of Antioxidant Properties}

\section{2, 2-Diphenyl -1- Picrylhydrazyl (DPPH) Radical Scavenging Activity Assay}

The free radical scavenging activity of the samples was determined according to the method of Kumari et al. (2016). A freshly prepared solution of DPPH in methanol $\left(6 \times 10^{-5}\right.$ M) was used for the UV measurements. The samples of different concentrations $(4-64 \mu \mathrm{g} / \mathrm{mL})$ were added to DPPH solution in 1:1 ratio followed by vortexing. Then, it was allowed to take place in the dark at room temperature. Ascorbic acid and trolox were utilized as a standard. The inhibition percentage of DPPH radical scavenging activity was calculated using the following equation.

$$
\operatorname{Inhibition}(\%)=\left[\left(A_{0}-A\right) / A_{0}\right] \times 100
$$

Where, $A_{0}$ is the absorbance of DPPH in the absence of the sample and $A$ is the absorbance of DPPH in the presence of the sample.

The $\mathrm{IC}_{50}$ values (the concentration required to scavenge $50 \%$ of the free radical) were estimated from a plot of $\%$ inhibition against the concentration of the sample solutions.

\section{Total Reduction Capability}

The total reduction capability of samples was determined according to the method of Kumari et al. (2016). $2.5 \mathrm{~mL}$ of $0.2 \mathrm{M}$ phosphate buffer ( $\mathrm{pH} \mathrm{6.6)}$ and $2.5 \mathrm{~mL}$ of $1 \%$ potassium ferric cyanide were added to $1 \mathrm{~mL}$ of samples in different concentrations $(4-64 \mu \mathrm{g} / \mathrm{mL})$, followed by gentle mixing. The mixture was incubated at $50^{\circ} \mathrm{C}$ in a water bath for $20 \mathrm{~min}$. The reaction was stopped by adding $2.5 \mathrm{~mL}$ of $10 \%$ TCA and the mixture was centrifuged at $4000 \mathrm{rpm}$ for $10 \mathrm{~min}$. From the top layer, $2.5 \mathrm{~mL}$ was transferred into the tube containing $2.5 \mathrm{~mL}$ distilled water and $0.5 \mathrm{~mL}$ of $0.1 \%$ ferric chloride $\left(\mathrm{FeCl}_{3} \cdot 6 \mathrm{H}_{2} \mathrm{O}\right)$, mixed thoroughly. After $5 \mathrm{~min}$, the absorbance was measured at $700 \mathrm{~nm}$ against blank. Trolox and ascorbic acid were taken as a standard.

\section{ABTS $^{+}$Radical Cation Decolorization Assay}

The antioxidant activities of the extracts were determined by the improved $\mathrm{ABTS}^{+}$radical cation scavenging ability with the slight modification (Re et al., 1999; Sarma et al., 2016). ABTS ${ }^{+}$ radical cation was produced by mixing $7 \mathrm{mM} \mathrm{2,2}$ - azinobis (3-ethylbenzothiazoline-6-sulfonic acid) diammonium salt (ABTS) and $2.45 \mathrm{mM}$ potassium persulfate $\left(\mathrm{K}_{2} \mathrm{~S}_{2} \mathrm{O}_{8}\right)$, incubated at room temperature in the dark. To determine the ABTS radical scavenging activity, $3 \mathrm{~mL}$ of $\mathrm{ABTS}^{+}$solution was mixed thoroughly with $0.2 \mathrm{~mL}$ of different concentration $(4-64 \mu \mathrm{g} / \mathrm{mL})$ of extracts. Ascorbic acid and trolox were taken as a standard. The reaction mixture was allowed to stand at room temperature for $6 \mathrm{~min}$.

The percentage inhibition was calculated by the following formula:

$$
\begin{aligned}
\text { \%Inhibition }= & \text { OD of control }- \text { OD of sample/ } \\
& \text { OD of control } \times 100
\end{aligned}
$$

\section{Hydrogen peroxide $\left(\mathrm{H}_{2} \mathrm{O}_{2}\right)$ Radical Scavenging Activity}

Hydrogen peroxide $\left(\mathrm{H}_{2} \mathrm{O}_{2}\right)$ radical scavenging activities of the extracts were determined according to the method of Sarma et al. (2016). Briefly, water extracts of C. asiatica $(4-64 \mu \mathrm{g} / \mathrm{mL})$ were added to $0.6 \mathrm{~mL} \mathrm{H}_{2} \mathrm{O}_{2}(40 \mathrm{mM})$ with the prepared phosphate buffer ( $\mathrm{pH}$ 7.4). The reaction mixtures were incubated at room temperature for $10 \mathrm{~min}$. After the incubation, the reaction mixture read at $230 \mathrm{~nm}$ against the blank solution with phosphate buffer ( $\mathrm{pH}$ 7.4). Ascorbic acid and trolox were taken as a standard. The inhibition percentage was calculated based on the formula:

$$
\text { Percentage }(\%) \text { of inhibition }=\left(A_{1}-A_{2}\right) / A_{1} \times 100 .
$$

Where, $A_{1}$ - absorbance of the $\mathrm{H}_{2} \mathrm{O}_{2}$ and $A_{2}$ - absorbance of the reaction mixture with extract.

\section{Nitric Oxide (NO) Radical Scavenging Assay}

Nitric oxide (NO) radical scavenging assay was carried out by the method of Kumari et al. (2016). $0.6 \mathrm{~mL}$ of $10 \mathrm{mM}$ sodium nitroprusside was mixed with $1 \mathrm{~mL}$ of water extract of $C$. asiatica in different concentration $(4-64 \mu \mathrm{g} / \mathrm{mL})$. The mixture was incubated at $25^{\circ} \mathrm{C}$ for $150 \mathrm{~min}$, followed by mixing with $1.0 \mathrm{~mL}$ of pre-prepared Griess reagent ( $1 \%$ sulfanilamide, $0.1 \%$ naphthyl ethylenediamine dichloride, and $2 \%$ phosphoric acid). Ascorbic acid and trolox were taken as a standard. The absorbance was measured at $546 \mathrm{~nm}$. The inhibition was calculated by the following equation:

$$
\text { \%inhibition of NO radical }=\left[A_{0}-A_{1}\right] / A_{0} \times 100 \text {. }
$$

Where, $A_{0}$ is the absorbance before the reaction and $A_{1}$ is the absorbance after the reaction has taken place with Griess reagent.

The decreasing absorbance indicates a high NO scavenging activity. 


\section{In vitro Lipid Peroxidation (LPO) Assay Preparation of rat liver homogenate}

Adult Wistar albino rats (150-200 g) were anesthetized with sodium pentobarbitone $\left(35 \mathrm{mg} \mathrm{kg}^{-1}\right)$ followed by excision of one lobe of the liver and washing with $0.9 \% \mathrm{NaCl}$ solution. Tissue homogenate was prepared in a ratio of $1 \mathrm{~g}$ wet tissue to 10 times (w/v) $0.05 \mathrm{M}$ ice-cold phosphate buffer ( $\mathrm{pH}-7.5)$ and homogenized by using Teflon homogenizer. The homogenate was used for the estimation of thiobarbituric acid reactive substances (TBARSs).

\section{TBARS assay}

The LPO of $C$. asiatica extract was determined according to the method of Kumari et al. (2016). Liver homogenate $(0.25 \mathrm{~mL})$ was mixed with $0.1 \mathrm{~mL}$ Tris HCL buffer ( $\mathrm{pH} 7.2), 0.05 \mathrm{~mL}$ of $0.1 \mathrm{mM}$ ascorbic acid, $0.05 \mathrm{~mL} 4 \mathrm{mM} \mathrm{FeCl}_{2}$ solution and $0.05 \mathrm{~mL}$ of the test extracts. All extracts were tested at five different concentrations $(4-64 \mu \mathrm{g} / \mathrm{mL})$. The mixture was incubated at $37^{\circ} \mathrm{C}$ for $1 \mathrm{~h}$ and then $1.5 \mathrm{~mL} 0.8 \%(\mathrm{w} / \mathrm{v}) 2$ - thiobarbituric acid, $1.5 \mathrm{~mL} 20 \%$ acetic acid, and $0.2 \mathrm{~mL} 8.1 \%(\mathrm{w} / \mathrm{v})$ sodium dodecyl sulfate were added to the reaction mixture. The mixture was made up to $4.0 \mathrm{~mL}$ with distilled water and heated at $95^{\circ} \mathrm{C}$ for $60 \mathrm{~min}$. After cooling with tap water, $1.0 \mathrm{~mL}$ distilled water and $5.0 \mathrm{~mL}$ of a mixture of $\mathrm{n}$-butanol and pyridine (15:1, v/v) were added. The mixture was shaken vigorously. The absorbance was measured at $532 \mathrm{~nm}$ in a spectrophotometer (Beckman, UK). Ascorbic acid and trolox were taken as a standard.

\section{In vivo Study}

\section{Experimental Animals and Ethics Statement}

All the experiments were conducted by using laboratorybred male Wistar albino rats at IASST, Guwahati, Assam, in accordance with the internationally accepted guideline for experimental animals use and the study was approved by the Institute Animal Ethics Committee (IAEC) (1706/GO/c/13/CPCSEA), IASST. All animals were housed under controlled conditions of temperature $\left(24 \pm 3^{\circ} \mathrm{C}\right)$, relative humidity $(60 \pm 10 \%), 12 / 12 \mathrm{~h}$. light-dark cycle, and water ad libitum the animal house of the IASST. Wister rats (male) weighing between 150 and $200 \mathrm{~g}$ were utilized for animal experiments.

\section{Acute Toxicity Study}

Acute toxicity test was conducted in $\mathrm{C} 3 \mathrm{H}$ mice $(n=6)$ following the Organization for Economic Co-operation and Development (OECD) protocol. The animals were kept fasting overnight except water ad libitum and administered with a single dose of $5 \mathrm{mg} / \mathrm{kg}$ body weight (b.w.) with under observation for a period of 14 days. As per the protocol mandate, (i) if mortality was observed in two out of three animals, then the dose administered was assigned as toxic dose, (ii) If mortality took place for single out of three, the dose was repeated to confirm the toxicity, (iii) if there was no mortality at all, the dose specificity had been raised to the maximum of $2,000 \mathrm{mg} / \mathrm{kg}$ b.w.

\section{Induction of Hyperlipidemic, Experimental Design, and Treatment Schedule}

For the development of hyperlipidemic conditions, rats weighing between 150 and $200 \mathrm{~g}$ were fed with high-cholesterol-diet (HCD), consisting of cholesterol $2 \%$, whole wheat $62.5 \mathrm{~g}$, yellow corn $37.5 \mathrm{~g}$, barley, vitamin $\mathrm{B}_{12}$ one tablet. The cholesterol solution was prepared under the requirement of $25 \mathrm{mg} / \mathrm{kg} \mathrm{b.w.} \mathrm{of}$ rat by dissolving the cholesterol in refined groundnut oil $(0.5 \%$ $w / v)$ (Khanna et al., 2002). Each individual animal was given $12 \mathrm{~g}$ of diet per day. All groups were subjected to intragastric administration every day till 28 days. After allowing a week for acclimatization, the rats were divided into six groups (six rats per group). Group A: normal diet and water (control). Group B: normal diet + cholesterol (25 mg/kg b. w.)/day. Group C: normal diet + cholesterol $(25 \mathrm{mg} / \mathrm{kg}$ b.w./day $)+$ fenofibrate $(65 \mathrm{mg} / \mathrm{kg}$ b.w./day). Group D: normal diet + cholesterol (25 mg/kg b.w./day) $+\mathrm{CAE}_{1}(0.25 \mathrm{~g} / \mathrm{kg}$ b.w./day). Group E: normal diet+ cholesterol (25 mg/kg b.w./day) $+\mathrm{CAE}_{2}$ (0.5 g/kg b.w./day). Group F: normal diet+ cholesterol $(25 \mathrm{mg} / \mathrm{kg}$ b.w./day $)+\mathrm{CAE}_{3}$ ( $1 \mathrm{~g} / \mathrm{kg}$ b.w./day) up to 28 days.

\section{Collection of Heart, Liver, and Serum}

At the end of the experiment, all feed was removed $14 \mathrm{~h}$ before anesthesia. After being anesthetized, the heart, liver, kidney from rat were removed and weighed. The livers were collected and stored at $-80^{\circ} \mathrm{C}$ for further analyses. Blood samples were also collected by an intracardiac puncture followed by separation of serum from the blood samples and collection in heparinized tubes. The collected serum samples were mixed gently by inverting 2-3 times and incubation at $4^{\circ} \mathrm{C}$ for $2-3 \mathrm{~h}$. Plasma was also separated from blood by centrifugation at $2500 \mathrm{rpm}$ for $30 \mathrm{~min}$, which was aliquoted and stored at $4^{\circ} \mathrm{C}$ until further use (Feng et al., 2015).

\section{Preparation of Tissue Homogenate}

Tissue homogenate (rat brain, liver, heart, and kidney) was prepared in a ratio of $1 \mathrm{~g}$ of wet tissue to 10 times (w/v) $0.05 \mathrm{M}$ ice-cold phosphate buffer ( $\mathrm{pH}$ 7.4) and homogenized by using a Teflon homogenizer. $0.2 \mathrm{~mL}$ of homogenate was used for estimation of TBARS. The remaining part of the homogenate was divided into two parts, one part of which was mixed with $10 \%$ TCA (1:1), centrifuged at $5000 \mathrm{rpm}\left(4^{\circ} \mathrm{C}\right.$, for $\left.10 \mathrm{~min}\right)$ and the supernatant was used for GSH estimation. The other part of the homogenate was centrifuged at $15000 \mathrm{rpm}$ at $4^{\circ} \mathrm{C}$ for $60 \mathrm{~min}$, the supernatants were used for SOD estimation.

\section{Biochemical Analysis \\ Blood lipid profile analysis}

Total cholesterol, TG, and HDL-C in serum were determined using test kits from Accurex Biomedical Pvt. Limited. Low density lipoprotein cholesterol (LDL-C) and very low density lipoprotein cholesterol (VLDL-C) were calculated using Friedwald's formula (Friedwald's et al., 1972).

\section{Evaluation of tissue markers of oxidative stress}

Thiobarbituric acid reactive substances were measured as a marker of lipid peroxidation for plasma, heart, and liver tissues by using the procedure described by Ohkawa et al. (1979), while 
glutathione (GSH) by Ellman (1959) and superoxide dismutase (SOD) (Marklund and Marklund, 1974). Nitrate/nitrites (NO) level was assayed by using the method described by Green et al. (1982).

\section{Histopathological Evaluation}

Rats were fed diets for 4 weeks. Upon termination of the experiment, food was withheld from the rat for $24 \mathrm{~h}$ before sacrifice. Rat were then anesthetized, and livers were immediately excised, weighed and stored at $80^{\circ} \mathrm{C}$ for further use, or fixed in $10 \%$ buffered formalin at room temperature for histological analysis. For hepatic histological examination, formalin-fixed liver samples were embedded in paraffin, sectioned and stained with hematoxylin and eosin (H\&E), and subjected to light microscope observation.

\section{Statistical Analysis}

The statistical analysis was carried out using the OriginPro 9.0 software packages (OriginLab Corporation, Northampton, MA, USA) and the statistical Pearson's correlation coefficients by using the OriginPro 6.0 software packages (OriginLab Corporation, Northampton, MA, USA). The results were determined by using one-way ANOVA and $p<0.05$ were set as significant. $\mathrm{IC}_{50}$ was calculated using GraphPad PRISM, version 6.03 for windows (GraphPad software). All the measurements were performed in triplicate $(n=3)$. Mean values \pm SD were calculated.

\section{RESULTS}

\section{Identification of Phenolic Compounds}

The screening and identification of $C$. asiatica extract was performed by UHPLC-ESI-MS/MS. The chromatographic runs are illustrated in Figure $\mathbf{1}$ and Supplementary Figure S1. It reveals the observation of intense peaks at 0-20 min. The peak identification was performed by comparison of the retention time (RT), $\lambda$ max, and mass spectra of the C. asiatica with the standard compounds and the earlier literature reports. Peaks with RTs (min) of 1.62, 1.72, 1.87, 1.88, 2.24 (peaks 1-5) were identified as the following: gulonic acid (RT 1.62, [M-H]- ion at $\mathrm{m} / \mathrm{z} 195.81, \lambda$ $\max 275 \mathrm{~nm}$ ), ferulic acid (RT 1.72, $[\mathrm{M}-\mathrm{H}]^{-}$ion at $\mathrm{m} / \mathrm{z} 193.81, \lambda$ $\max 275 \mathrm{~nm}$ ), kaempferol (RT 1.87, $[\mathrm{M}+\mathrm{H}]^{+}$ion at $\mathrm{m} / \mathrm{z} 287.89$, $\lambda \max 275 \mathrm{~nm}$ ), chlorogenic acid (RT 1.88, $[\mathrm{M}-\mathrm{H}]^{-}$ion at $\mathrm{m} / \mathrm{z}$ $353.09, \lambda \max 275 \mathrm{~nm}$ ), and asiatic acid (RT 2.24, $[\mathrm{M}-\mathrm{H}]^{-}$ion at $\mathrm{m} / \mathrm{z} 487.34, \lambda \max 275 \mathrm{~nm})$.

\section{In vitro Antioxidant Activities DPPH Radical Scavenging Activity}

The reduction capability of DPPH radicals was determined by the decrease in its absorbance at $517 \mathrm{~nm}$ induced by extracts having antioxidant potential. It produced hydrazine by converting the unpaired electrons to paired electron due to the hydrogen donating ability of the extract (Ozsoy et al., 2008). As shown in Figure 2A, at a concentration of $64 \mu \mathrm{g} / \mathrm{mL}$, the $\mathrm{IC}_{50}$ values of water extracts of $C$. asiatica, trolox, and ascorbic acid were $9.62 \pm 0.88,14.32 \pm 1.6$, and $6.93 \pm 0.76 \mu \mathrm{g} / \mathrm{mL}$, respectively. In this present study, the $\mathrm{IC}_{50}$ value of $C$. asiatica extract was demonstrated significantly higher free radical scavenging activity compared to the standard, trolox while the lowering $\mathrm{IC}_{50}$ value indicates a higher free radical scavenging activity (Figure 3).

\section{Total Reduction Capability}

The reducing ability of the extract was determined by the methods (Ahmed et al., 2013; Kumari et al., 2016). The reduction capability of the tested plant extract was increased with the increasing concentration in trolox and ascorbic acid equivalent as shown in Figure 2B. From the analysis, the absorbance of C. asiatica at $64 \mu \mathrm{g} / \mathrm{mL}$ was 0.18 respectively. Trolox and ascorbic acid were used as positive control and its reducing power at $64 \mu \mathrm{g} / \mathrm{mL}$ were 0.21 and 0.28 . The results showed a concentration-dependent significant increase $(p<0.05)$ in the reductive ability of the test samples. These results demonstrated that $C$. asiatica extract had marked the difference in ferric ions $\left(\mathrm{Fe}^{3+}\right)$ reducing ability as compared to the ascorbic acid.

\section{ABTS Radical Cation Decolourization Assay}

The $\mathrm{ABTS}^{+}$radical scavenging ability is an important method for determining the antioxidant ability. ABTS, a protonated radical, has characteristic absorbance maxima at $734 \mathrm{~nm}$, which decreases with the scavenging capacity (Wang et al., 1998). The results from the $\mathrm{ABTS}^{+}$radical scavenging ability was found to be high in $C$. asiatica $\left(\mathrm{IC}_{50}=27.21 \mu \mathrm{g} / \mathrm{mL}\right.$ ) followed by ascorbic acid $\left(\mathrm{IC}_{50}=12.06 \pm 1.06 \mu \mathrm{g} / \mathrm{mL}\right)$ and trolox $(12.76 \pm 2.1 \mu \mathrm{g} / \mathrm{mL})$ (Figure 3). C. asiatica, ascorbic acid and trolox exhibited the dose-dependent effective antioxidant activity (Figure 2C).

\section{Hydrogen Peroxide $\left(\mathrm{H}_{2} \mathrm{O}_{2}\right)$ Radical Scavenging Activity}

Hydroxyl radicals are extremely reactive free radicals formed in the biological system and there is no any specific enzymes to defend against them in human (Liu et al., 2005). The scavenging ability of $C$. asiatica, ascorbic acid and trolox are shown in Figure 2D. $\mathrm{H}_{2} \mathrm{O}_{2}$ radical scavenging ability of extracts of $C$. asiatica, ascorbic acid and trolox at the concentration of $64 \mu \mathrm{g} / \mathrm{mL}$ were $59.93 \pm 1.07,69.96 \pm 1.07$, and $66.43 \pm 1.4 \%$, respectively. The $\mathrm{IC}_{50}$ values of $C$. asiatica, ascorbic acid and trolox found to be $18.23 \pm 2.1,7.6 \pm 2.51$, and $13.43 \pm 1.4 \mu \mathrm{g} / \mathrm{mL}$, respectively. The $\mathrm{IC}_{50}$ value indicates that the plant extract is a better hydroxyl radical scavenger, which quite comparable with the standard ascorbic acid and trolox (Figure 3). In our study, the hydroxyl radical scavenging activity was increased by the extract with increasing concentration.

\section{Nitric Oxide (NO) Radical Scavenging Activity}

From the analysis, the water extract of $C$. asiatica showed the highest inhibitory effect with the $\mathrm{IC}_{50}$ value of $28.15 \pm 2.01 \mu \mathrm{g} / \mathrm{mL}$ at the concentration of $64 \mu \mathrm{g} / \mathrm{mL}$. In contrast, trolox and ascorbic acid showed the inhibitory effect with the $\mathrm{IC}_{50}$ value $18.53 \pm 1.7$, and $21.93 \pm 3.2 \mu \mathrm{g} / \mathrm{mL}$, respectively (Figure 3). Therefore, NO radical scavenging activity of $C$. asiatica was quite comparable to trolox and ascorbic acid at the concentration of $64 \mu \mathrm{g} / \mathrm{mL}$ (Figure 2E). Earlier reports demonstrate that the phenolic compounds play a vital role in NO suppression, which might be the reason behind differential inhibitory effect observed in this study (Kumari et al., 2016). 


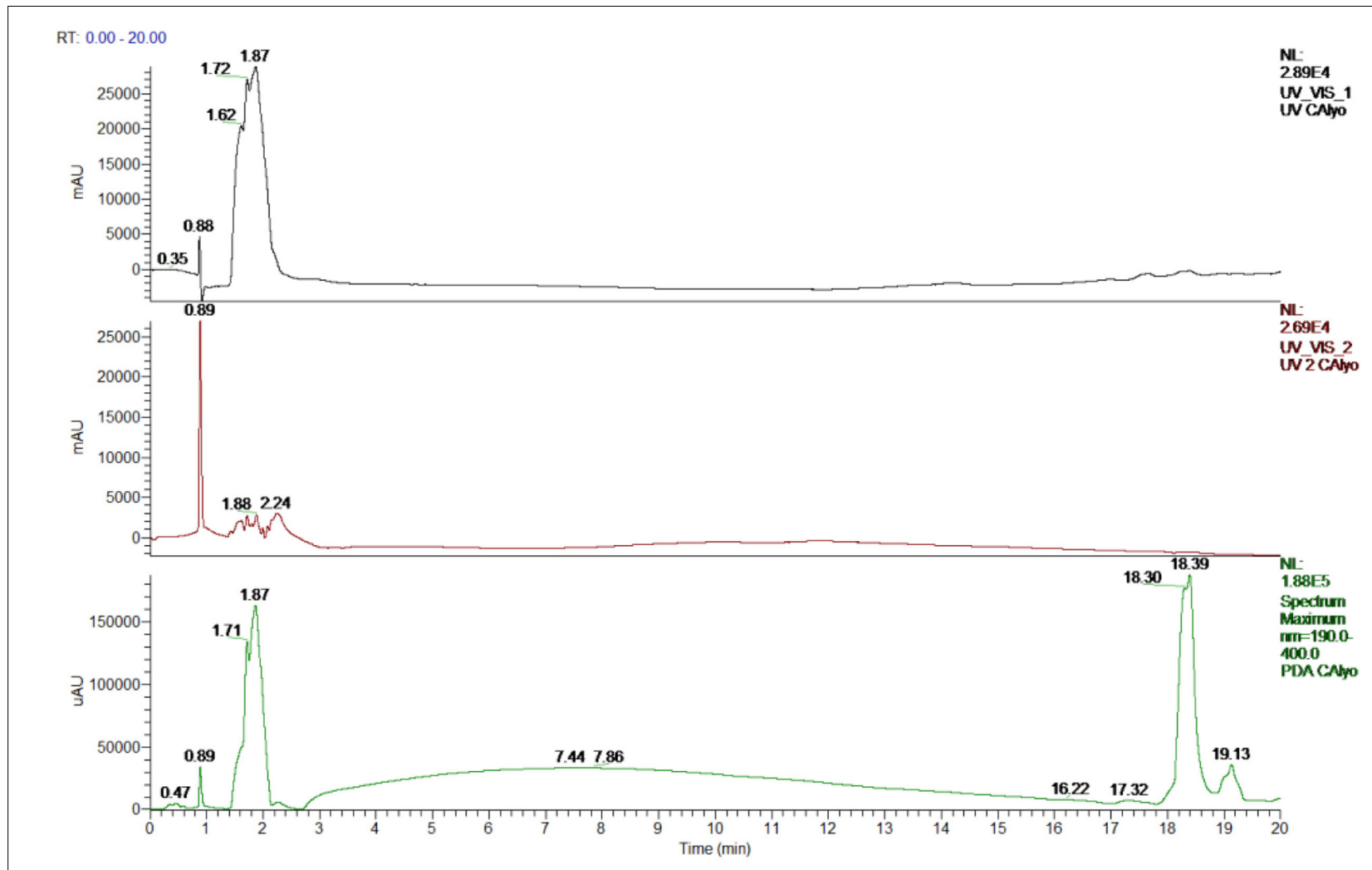

FIGURE 1 | Ultra-high performance liquid chromatography (UHPLC) chromatogram at 265, 354, 190-400 nm range of C. asiatica extract.

\section{Inhibition of Lipid Peroxidation (LPO)}

In this assay, LPO was significantly inhibited by plant extracts in a dose-dependent manner (Figure 2F). The inhibition at the concentration of $64 \mu \mathrm{g} / \mathrm{mL}$ is followed in the order, C. asiatica $<$ trolox $<$ Ascorbic acid. C. asiatica showed the highest inhibition of LPO with $60.53 \pm 2.21 \%(p<0.05)$, at the concentration of $64 \mu \mathrm{g} / \mathrm{mL}$ whereas trolox showed $75.66 \pm 1.45 \%$ of inhibitory effects. Additionally, ascorbic acid was also utilized as a positive control significantly inhibited LPO by $78.93 \pm 1.86 \%$. In addition, the $\mathrm{IC}_{50}$ values of $C$. asiatica, trolox, and ascorbic acid were recorded to be $42.13 \pm 2.32,14.21 \pm 1.01$, and $10.31 \pm 1.03 \mu \mathrm{g} / \mathrm{mL}$, respectively (Figure 3). It has been reported that phenolic compounds have shown more potential to prevent LPO and the associated diseases (Kumari et al., 2016). The results had clearly corroborated the efficacy of C. asiatica as a promising source of inhibiting LPO.

\section{Acute Toxicity and Effect of CAE on Body Weight}

The results of the acute oral administration of CAE in various doses up to $2000 \mathrm{mg} / \mathrm{kg}$ indicated no mortality up to 15 days after treatment. According to the acute toxicity studies of the ethanolic extract of CAE at a dose ranging from 2 to $5 \mathrm{~g}$ per $\mathrm{kg}$ body weight for 14 days did not manifest any significant and noticeable signs of toxicity in rats. In this study, after 28 days, the body weight of groups including normal or HCF feeding was significantly affected. The changes in body weight are shown in Table 2. The body weight was significantly increased in case of HCF fed groups than rats subjected to normal conditions (NCs) (two-way ANOVA, $p<0.05$ ). However, the body weight of hyperlipidemic rat treated with the three different dose levels of $\mathrm{CAE}\left(\mathrm{CAE}_{1}=0.25 \mathrm{~g} / \mathrm{kg}\right.$ b.w. $/$ day, $\mathrm{CAE}_{2}=0.5 \mathrm{~g} / \mathrm{kg}$ b.w./day, $\mathrm{CAE}_{3}=1 \mathrm{~g} / \mathrm{kg}$ b.w./day) demonstrated a remarkable decrease compared to the HCF group (one-way ANOVA, $p<0.05)$. This result was in agreement with previous work by who observed a marked decrease in body weight in CAE treated rats.

\section{Biochemical Parameters}

As shown in Table 3, serum lipids level (TC, TG, VLDL-C, and LDL-C) were increased significantly in HCF group in comparison to that of NC group $(p<0.05)$. Treatment with three different dose levels of CAE $\left(\mathrm{CAE}_{1}=0.25 \mathrm{~g} / \mathrm{kg}\right.$ b.w. $/$ day, $\mathrm{CAE}_{2}=0.5 \mathrm{~g} / \mathrm{kg}$ b.w./day, $\mathrm{CAE}_{3}=1 \mathrm{~g} / \mathrm{kg}$ b.w./day)in the HCF diet significantly lowered $(p<0.05)$ plasma TC by $35.7,39.81$, and $51.72 \%$, respectively and TG by $24.83,32.15$, and $38.83 \%$, respectively compared to the HCF groups. As far as the serum, treatment with $\mathrm{CAE}_{1}, \mathrm{CAE}_{2}$, and $\mathrm{CAE}_{3}$ elevated the HDL-C level and decline in the LDL-C contents. It was noted that CAE exhibited comparable potencies with those of fenofibrate on lipid parameters. Several studies have shown that TC, TC, TG, VLDL-C, and LDL-C level as biomarkers for hyperlipidemia (Stein and Stein, 1999; Devi and 


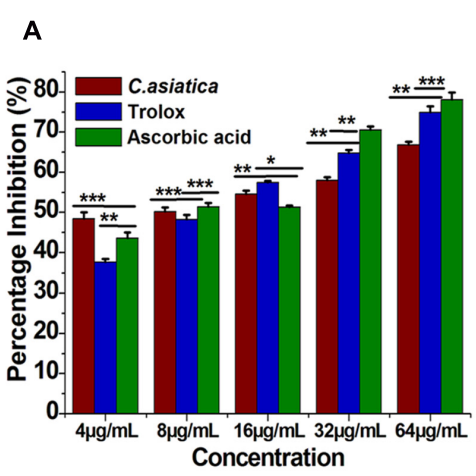

B

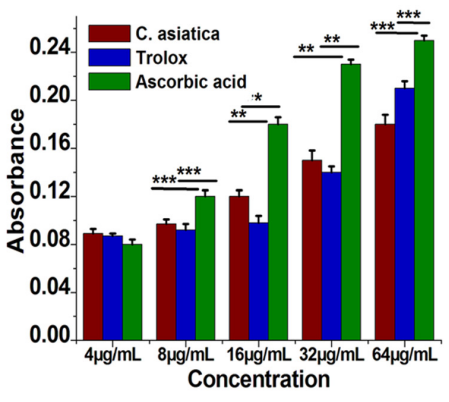

E

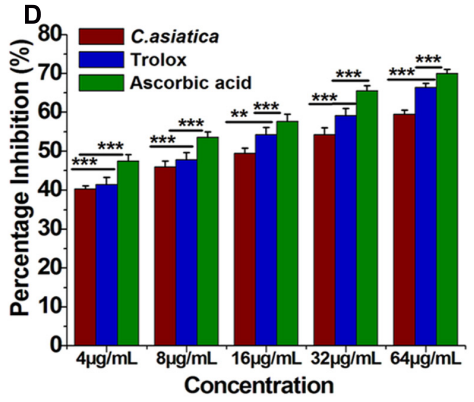

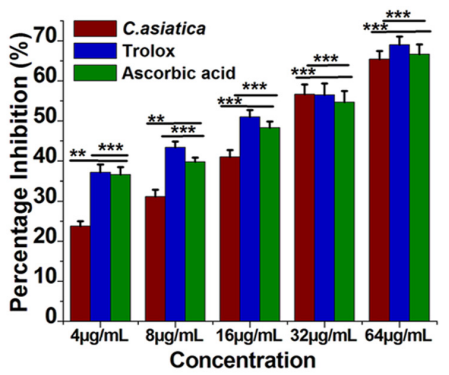

C
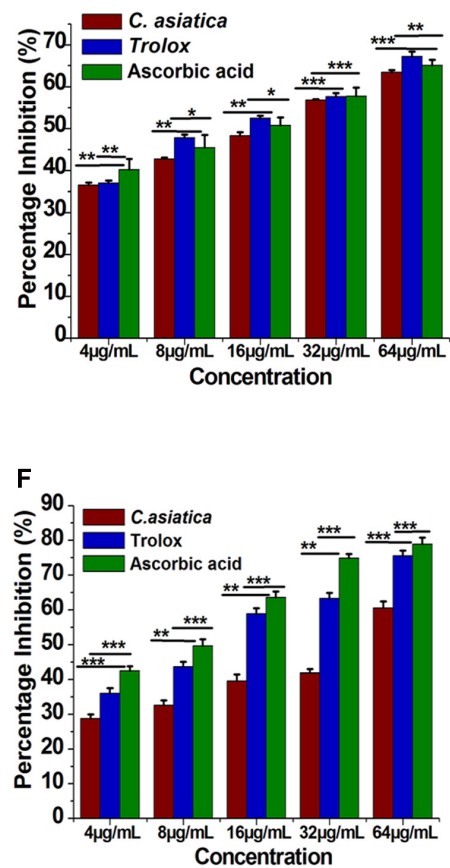

FIGURE 2 | Antioxidant activity of C. asiatica extract at different concentration (4-64 $\boldsymbol{\mu} \mathbf{g} / \mathbf{m L})$. (A) 2-2- Diphenyl-1-picryl-hydrazyl (DPPH) free radical scavenging activity. (B) Total reductive capability. (C) ABTS radical radical-scavenging ability. (D) $\mathrm{H}_{2} \mathrm{O}_{2}$ radical scavenging activity. (E) Nitric oxide (NO) radical-scavenging ability. (F) Lipid peroxidation assay. Each point represents the mean $\pm \operatorname{SD}(n=3)$. ${ }^{* * *},{ }^{* *}$, and ${ }^{*}$ shows statistical significant differences at $p<0.001, p<0.01$, and $p<0.05$.

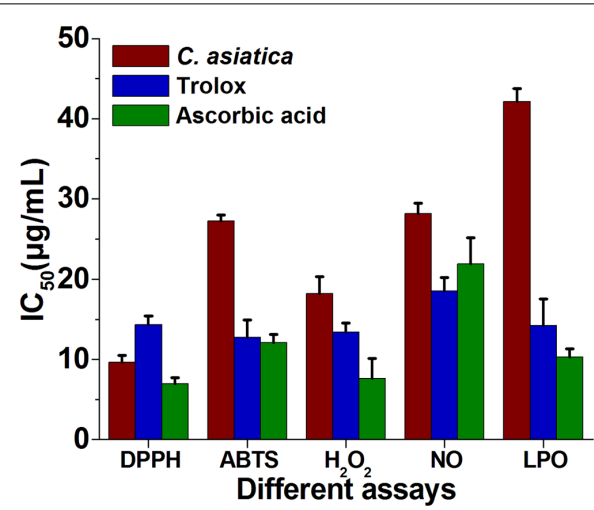

FIGURE 3 | The $\mathrm{IC}_{50}(\mu \mathrm{g} / \mathrm{mL})$ values of $C$. asiatica extracts for free radical scavenging activity by DPPH, ABTS, $\mathrm{H}_{2} \mathrm{O}_{2}$, NO, and LPO radical (Lower $\mathrm{IC}_{50}$ value indicates higher antioxidant activity).

Sharma, 2004). In this present work, CAE also improved the lipid profile, which was quite comparable with other studies (Stein and Stein, 1999; Devi and Sharma, 2004).

\section{Oxidative Stress Markers}

In hyperlipidemic condition, enzymatic as well as non-enzymatic antioxidative defense system such as SOD and reduced GSH are altered leading to reactive oxygen species (ROS) mediated damage (Devi and Sharma, 2004). As shown in Table 4, the OS markers (SOD, GSH, TBARS, and NO) levels increased significantly $(p<0.05)$ in serum, heart, and liver of HCF rats in comparison to that of NC group.

\section{Heart}

The level of SOD and GSH decreases significantly $(p<0.05)$ in stress induced HCF group heart tissue by 45 and $26.2 \%$, respectively when compared with those of NC groups. CAE treatment groups prevented the alterations in SOD and GSH levels in HCF group heart tissue homogenates, however, $\mathrm{CAE}_{1}, \mathrm{CAE}_{2}$, and $\mathrm{CAE}_{3}$ treatment group significantly increase $(p<0.01)$ the serum SOD level by 60.2, 70.3, and $78.1 \%$, respectively. In addition, $\mathrm{CAE}_{1}, \mathrm{CAE}_{2}$, and $\mathrm{CAE}_{3}$ and

TABLE 1 | Pearson's correlation coefficients between the five assays.

\begin{tabular}{lccccc}
\hline & DPPH & ABTS $^{+}$ & $\mathbf{H}_{\mathbf{2}} \mathbf{O}_{\mathbf{2}}$ & NO & LPO \\
\hline ABTS $^{+}$ & $0.969^{*}$ & - & $0.996^{* * *}$ & $0.997^{* * *}$ & $0.937^{*}$ \\
$\mathrm{H}_{2} \mathrm{O}_{2}$ & $0.965^{* *}$ & $0.996^{* * *}$ & - & $0.988^{* * *}$ & $0.942^{* *}$ \\
$\mathrm{DPPH}$ & - & $0.969^{*}$ & $0.965^{*}$ & $0.965^{*}$ & $0.991^{* * *}$ \\
$\mathrm{NO}$ & $0.965^{*}$ & $0.997^{* * *}$ & $0.988^{* * *}$ & - & $0.926^{*}$ \\
$\mathrm{LPO}$ & $0.991^{* *}$ & $0.937^{*}$ & $0.942^{*}$ & $0.926^{*}$ & - \\
\hline
\end{tabular}

*Correlation is significant at the 0.05 level.

** Correlation is significant at the 0.01 level.

*** Correlation is significant at the 0.001 level. 
TABLE 2 | Effect of various extracts of CAE (Centella asiatica extract) on body weight (b.w.) gram (g) in HCF- induced rats.

\begin{tabular}{lcc}
\hline Different group & $\begin{array}{c}\text { Initial body weight } \\
\text { (1st day) }\end{array}$ & $\begin{array}{c}\text { Final body weight } \\
\text { (28th day) }\end{array}$ \\
\hline $\mathrm{NC}$ & $173.5 \pm 2.21$ & $180.2 \pm 3.53$ \\
$\mathrm{HCF}$ & $188.2 \pm 2.85$ & $208.1 \pm 3.44$ \\
$\mathrm{HCF}+\mathrm{FF}$ & $177.2 \pm 4.23$ & $182.3 \pm 3.31$ \\
$\mathrm{HCF}+\mathrm{CAE}$ & $175.3 \pm 3.43$ & $189.2 \pm 2.73$ \\
$\mathrm{HCF}+\mathrm{CAE}$ & $178.22 \pm 2.11$ & $187.3 \pm 3.51$ \\
$\mathrm{HCF}+\mathrm{CAE}$ & $175.22 \pm 3.41$ & $184.41 \pm 2.97$ \\
\hline
\end{tabular}

CAE, Centella asiatica extract; NC, normal control; HCF, high cholesterol-fed; $\mathrm{HCF}+F F$, high cholesterol-fed + fenofibrate; $\mathrm{HCF}+C A E_{1}$, high cholesterol-fed + Centella asiatica extract 1 ( $0.25 \mathrm{~g} / \mathrm{kg}$ b.w./day); $\mathrm{HCF}+C A E_{2}$, high cholesterol-fed + Centella asiatica extract 2 ( $0.5 \mathrm{~g} / \mathrm{kg}$ b.w./day); $\mathrm{HCF}+\mathrm{CAE}_{3}$, high cholesterol-fed + Centella asiatica extract 3 (1 g/kg b.w./day).

significantly increases $(p<0.01)$ the GSH level by 35.2, 45.5, and $48.3 \%$, respectively. However, there were no significant differences in the other measured parameters.

\section{Serum}

In serum of HCF rat, the SOD level decreases significantly $(p<0.01)$ by $39.34 \%$ compared with those of NC group. $\mathrm{CAE}_{3}$ treatment group significantly increases $(p<0.01)$ the serum SOD level by $65.4 \%$. However, $\mathrm{CAE}_{1}$ and $\mathrm{CAE}_{2}$ treatment did not incorporate any significant changes in serum SOD parameters. However, there were no significant differences were detected in the other measured parameters.

\section{Liver}

The level of SOD and GSH were decreased significantly $(p<0.05)$ and TBARS increase significantly $(p<0.05)$ in liver homogenates of HCF group when compared with those of the NC group. $\mathrm{CAE}_{1}$, $\mathrm{CAE}_{2}$, and $\mathrm{CAE}_{3}$ treatment groups prevented the alterations in the level of SOD and GSH in HCF group. $\mathrm{CAE}_{1}, \mathrm{CAE}_{2}$, and $\mathrm{CAE}_{3}$ increases the $\operatorname{SOD}(30.21,45.1$, and $47.12 \%)$ and $\mathrm{GSH}$ $(23.3,30.21$, and 37.23$)$ level. TBARS level decreases significantly $(p<0.05)$ by $55.59 \%$. No changes were observed in the level of $\mathrm{NO}$ in CAE treated groups.

\section{Histopathological Observations in Liver Tissue Sections}

To further investigate hepatocyte morphological changes during the function of CAE, liver tissue sections using histopathological microscopy were examined. As shown in Figure 4, after 28 days of treatment with CAE, the liver cell structure of HCF rats in the high dose CAE treated group was integrated. The sizes of lipid droplets in the CAE group were remarkably smaller than those of HCF group, suggesting that CAE could reduce the accumulation of lipid droplets. In the present study, these data directly confirm that CAE treatment group can keep hepatocytes normal by preventing or reducing excess lipid formation in HCF rat.

\section{DISCUSSION}

The findings of this study demonstrated the antioxidant and antihyperlipidemic ability of extracts of $C$. asiatica by several in vitro and in vivo methods. The experimental results showed that extract of $C$. asiatica showed strong DPPH scavenging activity. Earlier reports demonstrated the $\mathrm{IC}_{50}$ value of $C$. asiatica in DPPH radical scavenging assay was in the range of $31.25 \mu \mathrm{g} / \mathrm{mL}$ (Pittella et al., 2009; Ahmed et al., 2013). However, in this study, the $\mathrm{IC}_{50}$ value of $C$. asiatica in $\mathrm{DPPH}$ radical scavenging assay was far lower $(\sim 8 \mu \mathrm{g} / \mathrm{mL})$ in comparison with the previous report (Pittella et al., 2009; Ahmed et al., 2013). Several previous reports demonstrated that the presences of the antioxidants in the extract were determined by assessing the ability of extract to reduce the ferric cyanide complex to the ferrous form (Ahmed et al., 2013; Kumari et al., 2016). The reducing power of a compound may serve as a significant indicator of its potential antioxidant activity (Pal et al., 2011). Samples with higher reducing power have better abilities to donate the electron and the free radical form stable substances by accepting the donated electrons, resulting in the termination of radical chain reaction (Deori et al., 2014). In our previous report, the polyphenolic compounds of $C$. asiatica showed significantly reduced the ferric cyanide complex to the ferrous form (reducing capabilities) at higher concentrations (Kumari et al., 2016). In the present study, the reducing ability of the extracts of $C$. asiatica was quite comparable (Figure 2B) with previous studies (Ahmed et al., 2013; Kumari et al., 2016). The previous report confirmed that the hydroxyl radicals are extremely reactive free radicals formed in the biological system and there are no any specific enzymes to defend against them in human (Liu et al., 2005). The presence of hydroxyl radical in the body may lead to the oxidative DNA damage. Therefore, it is very important to find the solution using natural products with good scavenging activity against this

TABLE 3 | Effect of various extracts of CAE (C. asiatica extract) on rats' serum lipid profile.

\begin{tabular}{|c|c|c|c|c|c|c|}
\hline Parameters (mg/dL) & NC & HCF & $\mathrm{HCF}+\mathrm{FF}$ & $\mathrm{HCF}+\mathrm{CAE}_{1}$ & $\mathrm{HCF}+\mathrm{CAE}_{2}$ & $\mathrm{HCF}+\mathrm{CAE}_{3}$ \\
\hline TC & $75.04 \pm 3.23$ & $162.52 \pm 5.5^{++}$ & $126.55 \pm 6.6^{*}$ & $104.4 \pm 3.21^{*}$ & $97.69 \pm 3.42^{*}$ & $78.43 \pm 2.46^{* *}$ \\
\hline TG & $64.47 \pm 3.31$ & $117.7 \pm 4.11^{+}$ & $97.34 \pm 4.47$ & $88.47 \pm 3.2$ & $79.85 \pm 2.03^{*}$ & $72.01 \pm 2.46^{* *}$ \\
\hline $\mathrm{HDL}$ & $64.69 \pm 3.42$ & $36.55 \pm 4.91^{+}$ & $42.73 \pm 2.12$ & $57.30 \pm 3.2$ & $59.03 \pm 4.21^{*}$ & $60.71 \pm 5.11^{*}$ \\
\hline LDL & $53.2 \pm 2.3^{++}$ & $138.92 \pm 4.2^{++}$ & $83.54 \pm 7.21$ & $58.13 \pm 5.6^{*}$ & $56.41 \pm 3.29^{*}$ & $54.73 \pm 3.45^{* *}$ \\
\hline VLDL & $16.83 \pm 2.72$ & $26.37 \pm 3.96^{+}$ & $21.44 \pm 3.94$ & $19.23 \pm 2.1$ & $18.78 \pm 1.03$ & $15.41 \pm 2.33^{*}$ \\
\hline
\end{tabular}

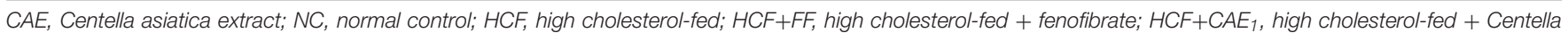

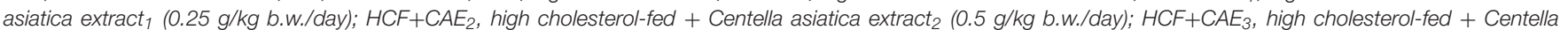
asiatica extract $3(1 \mathrm{~g} / \mathrm{kg}$ b.w./day).

${ }^{*} p<0.05$ vs. HCF group, ${ }^{* *} p<0.01$ vs. HCF group, ${ }^{+} p<0.05$ vs. NC group, ${ }^{++} p<0.01$ vs. NC group. $n=6, m e a n \pm S E M$. 
TABLE 4 | Changes in oxidative stress markers (SOD, CAT, GSH, TBARS, and NO) in heart, liver, and serum.

\begin{tabular}{|c|c|c|c|c|c|c|c|}
\hline \multicolumn{2}{|c|}{ Parameters } & \multirow{2}{*}{$\begin{array}{c}\text { NC } \\
69.45 \pm 3.4\end{array}$} & \multirow{2}{*}{$\begin{array}{c}\text { HCF } \\
38.16 \pm 1.15^{+}\end{array}$} & \multirow{2}{*}{$\begin{array}{c}\text { HCF+FF } \\
65.39 \pm 2.26\end{array}$} & \multirow{2}{*}{$\begin{array}{l}\mathbf{H C F}+\mathbf{C A E}_{\mathbf{1}} \\
61.16 \pm 0.01\end{array}$} & \multirow{2}{*}{$\begin{array}{l}\mathbf{H C F}+\mathrm{CAE}_{2} \\
64.99 \pm 1.5\end{array}$} & \multirow{2}{*}{$\begin{array}{c}\text { HCF+CAE1 } \\
67.99 \pm 1.5^{*}\end{array}$} \\
\hline Heart & SOD $^{a}$ & & & & & & \\
\hline & $\mathrm{GSH}^{\mathrm{b}}$ & $112 \pm 5.6$ & $60 \pm 3.2^{++}$ & $80 \pm 4$ & $81.82 \pm 2.7^{*}$ & $87 \pm 6.1^{* *}$ & $89 \pm 6.21^{* *}$ \\
\hline & TBARS $^{\mathrm{C}}$ & $35.2 \pm 1.6$ & $52.32 \pm 7.2^{+}$ & $41.1 \pm 2.3$ & $39.2 \pm 3.2$ & $38.61 \pm 2.5$ & $38.18 \pm 2.1$ \\
\hline & $\mathrm{NO}^{d}$ & $15.18 \pm 1.34$ & $27.14 \pm 1.32$ & $17.74 \pm 1.31$ & $21.32 \pm 2.21$ & $17.21 \pm 1.0$ & $13.21 \pm 1.0$ \\
\hline \multirow[t]{4}{*}{ Liver } & SOD $^{a}$ & $86.35 \pm 1.21$ & $55.14 \pm 1.11^{+}$ & $79.26 \pm 1.03$ & $70.31 \pm 1.12$ & $79.96 \pm 2.2$ & $81.16 \pm 1.2^{* *}$ \\
\hline & $\mathrm{GSH}^{\mathrm{b}}$ & $350 \pm 10$ & $258 \pm 6.5^{+}$ & $344 \pm 4.5$ & $318.17 \pm 8.5$ & $336 \pm 6.7$ & $356 \pm 6.6^{*}$ \\
\hline & TBARS $^{\mathrm{C}}$ & $76.4 \pm 5.3$ & $187.2 \pm 7.1^{++}$ & $147.57 \pm 8.1$ & $116.2 \pm 6.7$ & $97.66 \pm 7.230 .6$ & $82.4 .7 \pm 6.7^{* *}$ \\
\hline & $\mathrm{NO}^{\mathrm{d}}$ & $21.47 \pm 2.31$ & $47 \pm 3.26$ & $23.64 \pm 2.43$ & $33.34 \pm 2.7$ & $5 \pm 2.5$ & $24.65 \pm 0.5$ \\
\hline \multirow[t]{4}{*}{ Serum } & SOD $^{a}$ & $32.13 \pm 1.13$ & $19.49 \pm 2^{++}$ & $22.43 \pm 1.7$ & $26.56 \pm 5.23$ & $28.32 \pm 4.2$ & $32.25 \pm 2.1^{* *}$ \\
\hline & $\mathrm{GSH}^{\mathrm{e}}$ & $132 \pm 5.3$ & $201 \pm 7.3$ & $104 \pm 4$ & $114.89 \pm 2.7$ & $124.5 \pm 5$ & $130.2 \pm 7.5$ \\
\hline & TBARS $^{f}$ & $29.2 \pm 1.4$ & $46.92 \pm 3.6$ & $37.37 \pm 4.2$ & $33.1 \pm 2.27$ & $27.62 \pm 1.9$ & $28.81 \pm 2.1$ \\
\hline & $\mathrm{NO}$ & $26.63 \pm 1.51$ & $56.56 \pm 1.21$ & $23.82 \pm 1.51$ & $39.51 \pm 2.12$ & $33.19 \pm 1.1$ & $25.23 \pm 4.3$ \\
\hline
\end{tabular}

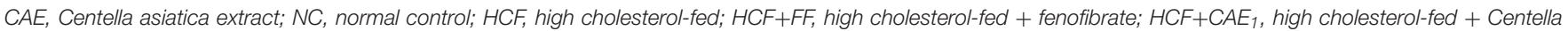

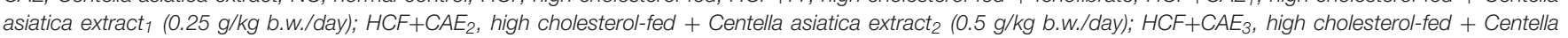
asiatica extract $3(1 \mathrm{~g} / \mathrm{kg}$ b.w./day).

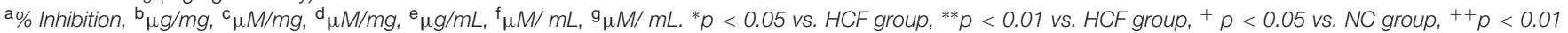
vs. NC group. $n=6$, mean \pm SEM.
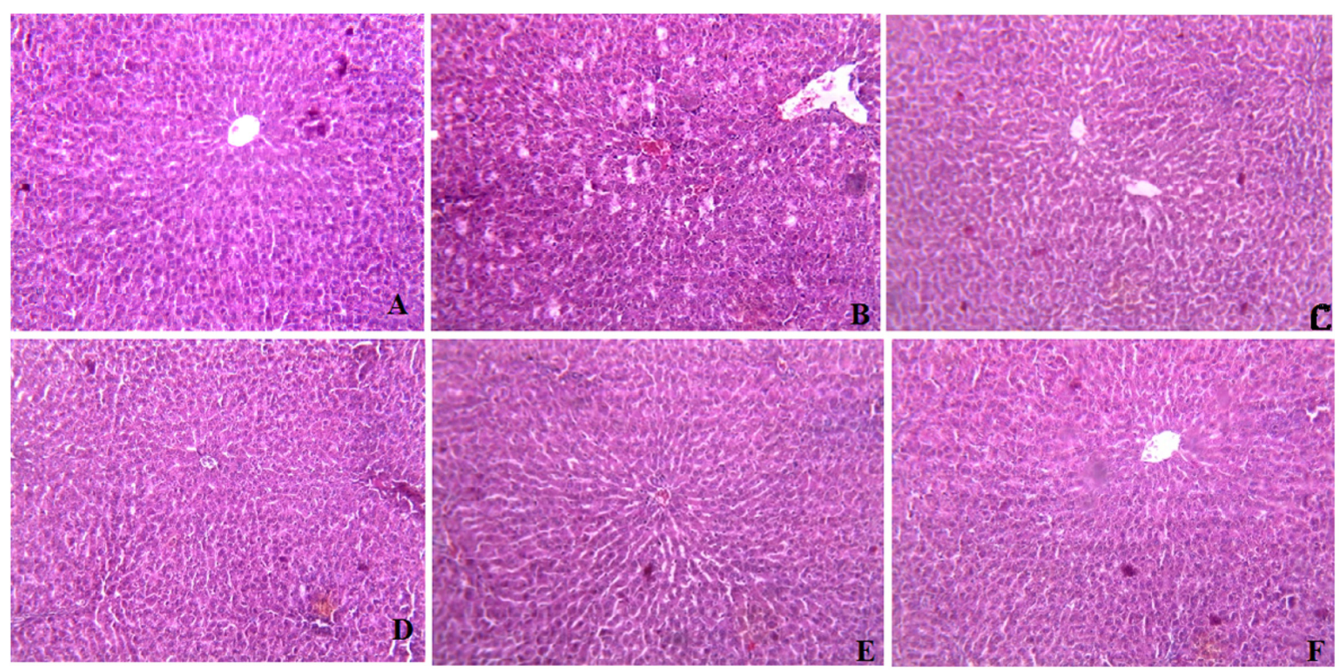

FIGURE 4 | Histopathological effects of C. asiatica extracts (CAE) in liver of High cholesterol-fed (HCF) rat (A) Represents Hematoxylin Eosine staining of normal liver with glomerulus. (B) High cholesterol-fed (HCF) liver with large area of necrosis, congested central vein (CV) and lipid droplets (LD) accumulation. (C) Fenofibrate treated liver showing restoration of hepatic structure. (D) $C_{1} E_{1}(0.25 \mathrm{~g} / \mathrm{kg})$ treated liver; (E) $C A E_{2}(0.5 \mathrm{~g} / \mathrm{kg})$ treated liver; (F) $C A E_{3}$ $(0.1 \mathrm{~g} / \mathrm{kg})$ treated liver; depicting improvement in the hepatic structure and sufficient reduction in the appearance of LD.

ROS. Earlier report also demonstrates that the scavenging of hydroxyl radical is an important antioxidant activity because of very high reactivity of the $\mathrm{OH}$ radical (Wang et al., 2008). In our study, each extract showed an increase in hydroxyl radical scavenging activity with increasing concentration of sample extracts. Overproduction of NO causes cancer, inflammation, neurodegenerative, chronic inflammatory diseases, ischemiareperfusion and other pathological conditions (Moncada et al., 1991; Bajpai et al., 2014). Earlier reports demonstrate that phenolic compounds play a vital role in NO suppression, which might be the reason behind the differential inhibitory effect, observed in this study (Kumari et al., 2016). In the present study, the extracts scavenging the $\mathrm{NO}$ which results in the reduction of chromophore formation, and decreases the absorbance with the increase in extract concentrations. We further confirm that the $\mathrm{ABTS}^{+}$radical scavenging activity of the extract of $C$. asiatica showed a good radical scavenging capacity with low $\mathrm{IC}_{50}$ value. LPO involves the generation of free radical and hydroxyl radical are the major active oxygen species causing LPO and enormous biological damage (Chidambaram et al., 2013). It is believed that LPO is one of the major causes of cardiovascular disease and cancer, generating malondialdehyde (MDA) like product during through a set of chemical reaction (Atmani et al., 2009). In the present study, LPO was significantly inhibited by all the extracts a dose-dependent manner. The inhibition at the concentration of $64 \mu \mathrm{g} / \mathrm{mL}$ followed order; C. asiatica $<$ trolox $<$ Ascorbic acid. 
The results had clearly corroborated the efficacy of C. asiatica as a promising source of inhibiting LPO. Earlier study demonstrated that the strong correlation between DPPH and ABTS methods (Floegel et al., 2011). In the present study, Table 1 shows the correlation between the five assays. DPPH was significantly and positively correlated with $\mathrm{ABTS}^{+}, \mathrm{H}_{2} \mathrm{O}_{2}, \mathrm{NO}$, and LPO. In the cases of $\mathrm{H}_{2} \mathrm{O}_{2}$, indicates strongly correlated with $\mathrm{ABTS}^{+}$and NO. Additionally, $\mathrm{ABTS}^{+}$and $\mathrm{NO}$ were significantly correlated with $\mathrm{H}_{2} \mathrm{O}_{2}$, but not DPPH and LPO.

Elevation of LDL-C and TC and reduction of high density lipoprotein level is associated with progression of atherosclerotic lesions (Harrison et al., 2003; Minhajuddin et al., 2005; Jain et al., 2007). In various studies, it has been reported that HCF rat significantly increased $(p<0.05)$ the levels of TC, HDL, LDL, VLDL, TGs, and also significantly decreased the level of HDL in the serum (Devi and Sharma, 2004). In this present work, CAE also improved the lipid profile, which was quite comparable with other studies (Stein and Stein, 1999; Devi and Sharma, 2004). In hyperlipidemic condition, enzymatic as well as non-enzymatic antioxidative defense system such as SOD and reduced GSH is altered leading to ROS mediated damage (Devi and Sharma, 2004). As shown in Table 4, the OS markers (SOD, GSH, TBARS, and NO) levels increased significantly $(p<0.05)$ in serum, heart, and liver of HCF rats in comparison to that of NC group. Earlier report also demonstrates that hypercholesterolemia diminishes the antioxidant defense system and decreases the activities of SOD and catalase in rats (Fki et al., 2005). Enzymes such as SOD and catalase which contribute to the antioxidant defense mechanism (Lee et al., 2002). However, in the present investigation, treatment with CAE increases the efficiency of SOD and GSH. Taken together, our result suggested that the administration of CAE could improve the efficiency of SOD and GSH. Furthermore, the previous report demonstrates that there is an increase of TBARS in the animal fed with a high cholesterol diet (Jiang et al., 2015). In addition, the decreased in the activity of these antioxidants can lead to an excess availability of superoxide anion and $\mathrm{H}_{2} \mathrm{O}_{2}$ in biological systems, which in turn generate hydroxyl radicals resulting in initiation and propagation of LPO (Kumuhekar and Katyane, 1992). In the present study, the similar increasing trend in TBARS level in HCF rat was observed. Herein, there was the preventive effect on the lipid peroxidation level by treatment with CAE extract. Earlier report also demonstrates that lipid drops are usually accumulated in hepatic tissue, called hepatic steatosis, under the progress of atherosclerosis, especially hyperlipidemia stage. However, enzymes such as SOD and catalase which contribute to the antioxidant defense mechanism and reducing excess lipid drops (Lee et al., 2002; Devi and Sharma, 2004). In the present study, these data directly confirm that CAE treatment group can keep hepatocytes normal by preventing or reducing excess lipid formation in HCF rat.

\section{CONCLUSION}

In this study, we have evaluated the antioxidant and antihyperlipidemic ability of extracts of C. asiatica. Herein, C. asiatica showed promising antioxidant and -antihyperlipidemic activities and also exhibited the highest phytochemical contents. The results of the present study indicate the presence of strong phenolic antioxidants components mainly gulonic acid, ferulic acid, kaempferol, chlorogenic acid, and asiatic acid in C. asiatica extract as evidenced from UHPLC-MS/MS. Additionally, CAE is capable of exhibiting significant anti-hyperlipidemic activities in HCF induced rat by enhancing parameters like antioxidant enzyme, body weight, and decrease serum lipid levels as well as regeneration of hepatic structures. Moreover, the CAE exerted to improve the hyperlipidemia induced hepatic structures by reducing OS, and restoring the antioxidant capacities. Taken together, this study strongly suggests that the CAE treatment might be an efficient way for treatment hyperlipidemia. This study has provided more evidence for the use of $C$. asiatica as a promising traditional medicine in the therapy of hyperlipidemia. Thus, these plant leaf extracts may be utilized as natural agents in food and pharmaceutical industries. Further studies are needed to isolate and identify the bioactive compounds present in the plant extracts and for the elucidation of their molecular mechanisms.

\section{AUTHOR CONTRIBUTIONS}

SK conceived and designed the experiment. SK, MD, RE performed the experiment. SK analyzed the data. SK and RE wrote the manuscript. JK and RD have done a critical revision of the manuscript for important intellectual content. RD has been the corresponding author and $\mathrm{MD}$ and RE shared as second authors. All authors have contributed to the final version and approved the final manuscript.

\section{FUNDING}

The authors would like to acknowledge Department of Science and Technology (DST) and Department of Biotechnology (DBT) (Government of India) for financial support.

\section{ACKNOWLEDGMENTS}

The authors also wish to acknowledge Dr. Nandana Bhardwaj, DBT BioCARe Scientist, IASST for critical suggestions and improvement during manuscript preparation. The authors also wish to acknowledge Mr. Anupam Bhattacharya, Research Associate, Bioinformatics Infrastructure Facility (BIF, IASST) and Miss. Shikha Mishra for the extreme help and support.

\section{SUPPLEMENTARY MATERIAL}

The Supplementary Material for this article can be found online at: http://journal.frontiersin.org/article/10.3389/fphar.2016. 00400/full\#supplementary-material 


\section{REFERENCES}

Ahmed, S. A., Hanif, S., and Iftkhar, T. (2013). Phytochemical profiling with antioxidant and antimicrobial screening of Amaranthus viridis $\mathrm{L}$. leaf and seed extracts. Open J. Med. Microbiol. 3, 164-171. doi: 10.4236/ojmm.2013.33025

Arsenault, B. J., Rana, J. S., Stroes, E. S., Després, J. P., Shah, P. K., Kastelein, J. J., et al. (2009). Beyond low-density lipoprotein cholesterol: respective contributions of non-high-density lipoprotein cholesterol levels, triglycerides, and the total cholesterol/high-density lipoprotein cholesterol ratio to coronary heart disease risk in apparently healthy men and women. J. Am. Coll. Cardiol. 55, 35-41. doi: 10.1016/j.jacc.2009.07.057

Atmani, D., Chaler, N., Berboucha, M., Ayouni, K., Lounis, H., and Boudaoud, H. (2009). Antioxidant capacity and phenol content of elected Algerian medicinal plants. Food Chem. 112, 303-309. doi: 10.1016/j.foodchem.2008.05.077

Bajpai, V. K., Sharma, A., Kang, S. C., and Baek, K. H. (2014). Antioxidant, lipid peroxidation inhibition and free radical scavenging efficacy of a diterpenoid compound sugiol isolated from Metasequoia glyptostroboides. Asian Pac. J. Trop. Med. 7, 9-15. doi: 10.1016/S1995-7645(13)60183-2

Berry, J. D., Dyer, A., Cai, X., Garside, D. B., Ning, H., Thomas, A., et al. (2012). Lifetime risks of cardiovascular disease. N. Engl. J. Med. 366, 321-329. doi: 10.1056/NEJMoa1012848

Chang, Y. Y., Chou, C. H., Chiu, C. H., Lin, Y. L., Yang, K. T., Weng, W. L., et al. (2011). Preventive effects of taurine on development of hepatic steatosis induced by a high-fat/cholesterol-dietary habit. J. Agric. Food Chem. 59, 450457. doi: $10.1021 /$ if103167u

Chidambaram, U., Pachamuthu, V., Natarajan, S., Elango, B., Narayanan, S., and Ramkumar, K. M. (2013). In vitro evaluation of free radical scavenging activity of Codariocalyxmotorius root extract. Asian Pac. J. Trop. Med. 6, 188-194. doi: 10.1016/S1995-7645(13)60021-8

Cragg, G. M., and Newman, D. J. (2007). Drug from nature: past achievement, future prospect. Adv. Phytomed. 1, 23-37. doi: 10.1016/S1572-557X(02)80010-1

de Lemos, J., Braunwald, E., Blazing, M., Murphy, S., Downs, J., Gotto, A., et al. (2010). Efficacy and safety of more intensive lowering of LDL cholesterol: a meta-analysis of data from 170,000 participants in 26 randomised trials. Lancet 376, 1670-1681. doi: 10.1016/S0140-6736(10)61350-5

Deori, M., Boruah, D. C., Devi, D., and Devi, R. (2014). Antioxidant and antigenotoxic effects of pupae of the muga silkworm Antheraea assamensis. Food Biosci. 5, 108-114. doi: 10.1016/j.fbio.2013.12.001

Devi, R., and Sharma, D. K. (2004). Hypolipidemic effect of different extracts of Clerodendron colebrookianum Walp in normal and high fat diet fed rats. J. Ethnopharmacol. 90, 63-68. doi: 10.1016/j.jep.2003.09.022

Ellman, G. L. (1959). Tissue sulphydryl groups. Arch. Biochem. Biophys. 82, 70-77. doi: 10.1016/0003-9861(59)90090-6

Feng, J., Fitz, Y., Li, Y., Fernandez, M., Cortes Puch, I., Wang, D., et al. (2015). Catheterization of the carotid artery and jugular vein to perform hemodynamic measures, infusions and blood sampling in a conscious rat model. J. Vis. Exp. 95:e51881. doi: 10.3791/51881

Fki, I., Bouaziz, M., Sahnoun, Z., and Sayadi, S. (2005). Hypocholesterolemic effects of phenolic-rich extracts of Chemlali olive cultivar in rats fed a cholesterol-rich diet. Bioorg. Med. Chem. 13, 5362-5370. doi: 10.1016/j.bmc.2005.05.036

Floegel, A., Kim, D. O., Chung, S. J., Koo, S. I., and Chun, O. K. (2011). Comparison of ABTS/DPPH assays to measure antioxidant capacity in popular antioxidant-rich US food. J. Food Compos. Anal. 24, 1043-1048. doi: 10.1016/j.jfca.2011.01.008

Friedwald's, W. T., Levy, I. R., and Frederickson, S. D. (1972). Estimation of concentration of low density lipoprotein cholesterol in plasma without use of the preparative ultracentrifuge. Clin. Chem. 18, 499-502.

Gohil, K. J., Patel, J. A., and Gajjar, A. K. (2010). Pharmacological review on Centella asiatica: a potential herbal cure-all. Indian J. Pharm. Sci. 72, 546-556. doi: 10.4103/0250-474X.78519

Gorinstein, S., Yamamoto, K., Katrich, E., Leontowicz, H., Lojek, A., Leontowicz, M., et al. (2003). Antioxidant properties of jffa sweeties and grape fruit and their influence on lipid metabolism and plasma antioxidative potential in rats. Biosci. Biotechnol. Biochem. 67, 907-910. doi: 10.1271/bbb.67.907

Green, L. C., Wagner, D. A., Glogowski, J., Skipper, P. L., Wishnok, J. S., and Tannenbaum, S. R. (1982). Analysis of nitrate, nitrite and [15N] nitrate in biological fluids. Anal. Biochem. 126, 131-138. doi: 10.1016/00032697(82)90118-X
Harchaoui, K., Visser, M., Kastelein, J., Stroes, E., and Dallinga-Thie, G. (2009). Triglycerides and cardiovascular risk. Curr. Cardiol. Rev. 5, 216-222. doi: $10.2174 / 157340309788970315$

Harrison, D., Kathy, K. G., Hornig, B., and Drexler, H. (2003). Role of oxidative stress in atherosclerosis. Am. J. Cardiol. 91, 7A-11A. doi: 10.1016/S00029149(02)03144-2

Hernandez, N. E., Tereschuk, M. L., and Abdala, L. R. (2000). Antimicrobial activity of flavonoids in medicinal plants from Tafí del Valle (Tucumain, Argentina). J. Ethnopharmacol. 73, 317-322. doi: 10.1016/S0378-8741(00)00295-6

Hsu, C. L., Chang, Y. Y., Chiu, C. H., Yang, K. T., Wang, Y., Fu, S. G., et al. (2011). Cardiovascular protection of deep-seawater drinking water in high-fat/ cholesterol fed hamsters. Food Chem. 127, 1146-1152. doi: 10.1016/j.foodchem.2011.01.116

Issa, A. V., Volate, S. R., and Wargovich, M. J. (2006). The role of phytochemicals in inhibition of cancer and inflammation: new directions and perspectives. J. Food Comp. Analysis 19, 405-419. doi: 10.1016/j.jfca.2006.02.009

Jain, K. S., Kathiravan, M. K., Somani, R. S., and Shishoo, C. J. (2007). The biology and chemistry of hyperlipidemia. Bioorg. Med. Chem. 15, 4674-4699. doi: 10.1016/j.bmc.2007.04.031

Jiang, C., Wang, Q., Wei, Y., Yao, N., Wu, Z., Maa, Y., et al. (2015). Cholesterollowering effects and potential mechanisms of different polar extracts from Cyclocarya paliurus leave in hyperlipidemic mice. J. Ethnopharmacol. 176, 17-26. doi: 10.1016/j.jep.2015.10.006

Joshi, K., and Chaturvedi, P. (2013). Therapeutic efficiency of Centella asiatica (L.) Urb. An underutilized green leafy vegetable: an overview. Int. J. Pharm. Bio. Sci. 4, 135-149.

Kaliora, A. C., Dedoussis, G. V. Z., and Schmidt, H. (2006). Dietary antioxidants in preventing atherogenesis. Atherosclerosis 187, 1-17. doi: 10.1016/j.atherosclerosis.2005.11.001

Khanna, A. K., Rizvi, F., and Chander, R. (2002). Lipid lowering activity of Phyllanthus niruri in hyperlipemicrats. J. Ethnopharmacol. 82, 19-22. doi: 10.1016/S0378-8741(02)00136-8

Kumari, S., Elancheran, R., Kotoky, J., and Devi, R. (2016). Rapid screening and identification of phenolic antioxidants in Hydrocotyle sibthorpioides Lam. by UHPLC-ESI-MS/MS. Food Chem. 203, 521-529. doi: 10.1016/j.foodchem.2016.02.101

Kumuhekar, H. M., and Katyane, S. S. (1992). Altered kinetic attributes of $\mathrm{Na}+\mathrm{K}+$ ATPase activity in kidney, brain and erythrocyte membrane in alloxankiabeticrats. Indian J. Exp. Biol. 30, 26-32.

Lee, M. K., Bok, S. H., Jeong, T. S., Moon, S. S., Lee, S. E., Yong, B. P., et al. (2002). Supplementation of naringenin and its synthetic derivative alters antioxidant enzyme activities of erythrocyte and liver in high cholesterol-fed rats. Bioorg. Med. Chem. 10, 2239-2244. doi: 10.1016/S0968-0896(02)00059-7

Liao, D. F., Jin, Z. G., Baas, A. S., Daum, G., Gygi, S. P., Aebersold, R., et al. (2000). Purification and identification of secreted oxidative stress-induced factors from vascular smooth muscle cells. J. Biol. Chem. 275, 189-196. doi: 10.1074/jbc.275.1.189

Lin, Y. L., Chang, Y. Y., Yang, D. J., Tzang, B. S., and Chen, Y. C. (2013). Beneficial effects of noni (Morinda citrifolia L.) juice on livers of high-fat dietary hamsters. Food Chem. 140, 31-38. doi: 10.1016/j.foodchem.2013.02.035

Liu, C. W., Yang, D. J., Chang, Y. Y., Hsu, C. L., Tseng, J. K., Chang, M. H., et al. (2012). Polyphenol-rich longan (Dimocarpus longan Lour.)- flower-waterextract attenuates non-alcoholic fatty liver via attenuating lipid peroxidation and down regulating matrix metalloproteinases-2 and -9. Food Res. Int. 45, 444-449. doi: 10.1016/j.foodres.2011.11.007

Liu, C. Z., Yu, J. C., Zhang, X. Z., Wang, T., and Han, J. X. (2005). On changes of activity of antioxidases in hippocampus rat with multi-infract dementia and the intervention effects of acupuncture. China J. Trad. Chin. Med. Pharm. 20, 724-726.

Lokho, A. (2012). The folk medicinal plants of the Mao Naga in Manipur, North East India. Int. J. Sci. Res. 2, 1-8.

Ma, Y., Wang, W., Zhang, J., Lu, Y., Wu, W., Yan, H., et al. (2012). Hyperlipidemia and atherosclerotic lesion development in Ldlr-deficient mice on a long-term high-fat diet. PLOS ONE 7:e35835. doi: 10.1371/journal.pone. 0035835

Marklund, S., and Marklund, G. (1974). Involvement of superoxide anion radical in auto oxidation of pyrogallol and a convenient assay for superoxide dismutase. Eur. J. Biochem. 47, 469-474. doi: 10.1111/j.1432-1033.1974.tb03714.x 
Maruthanila, V. L., Poornima, J., and Mirunalani, S. (2014). Attenuation of carcinogenesis and the mechanism underlying by the influence of indole-3-carbinol and its metabolite 3,3'-diindolylmethane: a therapeutic marvel. Adv. Pharmacol. Sci. 2014, 1-7. doi: 10.1155/2014/ 832161

Minhajuddin, M., Beg, Z. H., and Iqbal, J. (2005). Hypolipidemic and antioxidant properties of tocotrienol rich fraction isolated from rice bran oil in experimentally induced hyperlipidemic rats. Food chem. Toxicol. 43, 747-753. doi: 10.1016/j.fct.2005.01.015

Moncada, A., Palmer, R. M. J., and Higgs, E. A. (1991). Nitric oxide: physiology, pathophysiology and pharmacology. Pharmacol. Rev. 43, 109-142.

Ohkawa, H., Ohishi, N., and Yagi, K. (1979). Assay for lipid peroxides in animal tissues by thiobarbituric acid reaction. Anal. Biochem. 95, 351-358. doi: 10.1016/0003-2697(79)90738-3

Orhan, I. E. (2012). Centella asiatica (L.) Urban: from traditional medicine to modern medicine with neuroprotective potential. Evid. Based Complement. Alternat. Med. 2012: 946259. doi: 10.1155/2012/946259

Ozsoy, N., Can, A., Yanardag, R., and Akev, N. (2008). Antioxidant activity of smilax excels L leaf extracts. Food Chem. 110, 571-583. doi: 10.1016/j.foodchem.2008.02.037

Pal, R., Girhepunje, K., Shrivastav, N., Huain, M., and Trirumoorthy, N. (2011). Antioxidant and free radical scavenging activity of ethanolic extract of Morinda citrifolia. Ann. Biol. Res. 2, 127-131. doi: 10.1007/s11418-0090328-6

Pittella, F., Dutra, R. C., Dalton, D. J., Lopes, M. T. P., and Barbosa, N. R. (2009). Antioxidant and cytotoxic activities of Centella asiatica (L) Urb. Int. J. Mol. Sci. 10, 3713-3721. doi: 10.3390/ijms10093713

Polya, G. M. (2003). Biochemical Targets of Plant Bioactive Compound. A pharmacological References Guide to Sites of Action and Biological Effects. Boca Raton, FL: CRC Press.

Pronprapa, W., Michael, H. G., and Arunee, A. (2010). Flavour characterization of fresh and processes pennywort (Centella asiatica L.) Juices. Food chem. 119, 69-74. doi: 10.1111/j.1750-3841.2009.01358.x

Raghuveer, C., and Tandon, R. V. (2009). Consumption of functional food and our health concerns. Pak. J. Physiol. 5, 76-83.

Rai, P. K., and Lalramnghinglova, H. (2010). Lesser known ethnomedicinal plants of Mizoram, North East India: an Indo- Burma hotspot region. J. Med. Plants Res. 4, 1301-1307.

Re, R., Pellegrini, N., Proteggente, A., Pannala, A., Yang, M., and Rice- Evans, C. (1999). Antioxidant activity applying an improved ABTS radical cation decolorization assay. Free Radic. Biol. Med. 26, 1231-1237. doi: 10.1016/S08915849(98)00315-3

Sarma, R., Kumari, S., Ramakrishnan, E., Deori, M., and Devi, R. (2016). Polyphenol rich extract of Garcinia pedunculata fruit attenuates the
Hyperlipidemia induced by High Fat Diet. Front. Pharmacol. 7:294. doi: 10.3389/fphar.2016.00294

Sasaki, Y. F., Kawaguchi, S., Kamaya, A., Ohshita, M., Kabasawa, K., and Iwama, K. (2002). The comet assay with eight mouse organs: results with 39 currently food additives. Mutat. Res. 519, 103-119. doi: 10.1016/S1383-5718(02)00128-6

Seevaratna, V., Banumathi, P., Premalatha, M. R., Sundaram, S. P., and Arumugam, T. (2012). Functional properties of Centella asiatica (L.): a review. Int. J. Pharm. Pharm. Sci. 4(Suppl. 5), 8-14.

Shridhar, D. M. P., Mahajan, G. B., Kamat, V. P., Nail, C. C., Parab, R. R., Thakur, N. R., et al. (2009). Antibacterial activity of 2-(2', 4'-Dibromophenoxy) 4, 6- dibromophenol from Dysidea granulose. Mar. Drugs 7, 464-471. doi: $10.3390 / \mathrm{md} 7030464$

Somboonwong, J., Kankaisre, M., Tantisira, B., and Tantisira, M. H. (2012). Wound healing activities of different extracts of Centella asiatica in incision and burn wound models: an experimental animal study. BMC Complement. Altern. Med. 12:103. doi: 10.1186/1472-6882-12-103

Stein, O., and Stein, Y. (1999). Atheroprotective mechanism of HDL. Atherosclerosis 144, 285-301. doi: 10.1016/S0021-9150(99)00065-9

Wang, H., Gao, X. D., Zhou, G. C., Cai, L., and Yao, W. B. (2008). In vitro and in vivo antioxidant activity of aqueous extract from Choerospondias axillaris fruit. Food Chem. 106, 888-895.

Wang, M., Li, J., Rangarajan, M., Shao, Y., LaVoie, E. J., Huang, T., et al. (1998). Antioxidative phenolic compounds from sage (Salvia officinalis). J. Agric. Food Chem. 46, 4869-4873. doi: 10.1021/jf980614b

Yang, D. J., Chang, Y. Y., Hsu, C. L., Liu, C. W., Wang, Y., and Chen, Y. C. (2010). Protective effect of a litchi (Litchi chinensis Sonn.)-Flower-water-extract on cardiovascular health in a high-fat/cholesterol-dietary hamsters. Food Chem. 119, 1457-1464. doi: 10.1016/j.foodchem.2009.09.027

Yang, S. F., Tzang, B. S., Yang, K. T., Hsiao, Y. C., Chang, Y. Y., Chan, C. H., et al. (2010). Taurine alleviates dyslipidemia in hamsters fed a high-fat/cholesterol diet. Food Chem. 120, 156-162. doi: 10.1016/j.nutres.2013.04.006

Yu, B. P. (1994). Cellular defenses against damage from reactive oxygen species. Physiol. Rev. 76, 139-162.

Conflict of Interest Statement: The authors declare that the research was conducted in the absence of any commercial or financial relationships that could be construed as a potential conflict of interest.

Copyright (c) 2016 Kumari, Deori, Elancheran, Kotoky and Devi. This is an openaccess article distributed under the terms of the Creative Commons Attribution License (CC BY). The use, distribution or reproduction in other forums is permitted, provided the original author(s) or licensor are credited and that the original publication in this journal is cited, in accordance with accepted academic practice. No use, distribution or reproduction is permitted which does not comply with these terms. 